\title{
Family-work conflict and safety performance: An un- examined relationship in the Ghanaian mining industry
}

\author{
Prince Ewudzie Quansah*, Veronica Essinam Eggley**, Kobina Danful Fanyinkah ${ }^{* * *}$ \\ * School of Management, Jiangsu University, China \\ ** Department of Psychology and Education, University of Education, Winneba, Ghana \\ *** Department of Agricultural Science, University of Ghana, Legon \\ DOI: $10.29322 / I J S R P .10 .11 .2020 . p 10751$ \\ http://dx.doi.org/10.29322/IJSRP.10.11.2020.p10751
}

\begin{abstract}
Purpose - Studies on family-work conflict and job performance have received much attention. However, there are still unanswered questions about how family-work conflict affects specific job performance, such as safety performance. Therefore, this current study attempted to investigate the extent to which family-work conflict affects two kinds of safety performance, such as safety compliance and safety participation through the mediating role of job stress.

Design/methodology/approach -We developed a model that examined family-work conflict as the independent variable, job stress as a mediator variable, and safety compliance and safety participation of safety performance as the dependent variables. Using a questionnaire survey, we gathered 302 valid responses from contract mineworkers in Tarkwa, Ghana. We analysed the hypothesised relationships using the structural equation model.

Findings - From the results of our study, family-work conflict had a significant negative and positive effect on safety compliance and safety participation, respectively. Job stress also had a significant negative influence on safety compliance and safety participation. Furthermore, testing job stress as a mediator revealed that job stress could act as a partial mediator in the relationship between family-work conflict and all two dimensions of safety performance.

Originality/value -This current study is vital for managerial practices. Also, the structural model presents a different perspective on the impact of family-work conflict on safetyrelated issues.
\end{abstract}

Index Terms-family-work conflict; job stress; safety compliance; safety participation

\section{INTRODUCTION}

Family-work conflict describes the conditions when the demands of one's family and work domains are mutually incompatible, and due to that work participation becomes challenging by participation in family role (Greenhaus \& Beutell, 1985; Weer \& Greenhaus, 2014). Family-work conflict is vital for both the employer and the employee because it is associated with negative consequences. The family-work conflict tends to cause high occupational burnout, increased job stress, poor safety performance etc. Despite the negative impact family-work conflict can cause, very few studies have considered how it influences safety performance (Cullen \& Hammer, 2007; Smith,
Hughes, DeJoy, \& Dyal, 2018). Considering the mining operations where employees spend a lot of time and tortuous effort to get things done, the family-work conflict will be a severe issue to battle. According to KowalsKi-traKofler, Vaught, McWilliams, and Reisman (2011), the greatest challenge of coal mineworkers is their inability to balance their family demands with that of their job demands. This condition increased workers' stress level and affected their performance as well; hence, they could not meet their company's target (KowalsKi-traKofler et al., 2011). In the case of Ghana, where contract miners have a huge burden to achieve the high target to remain in the good books of the mother companies, it is anticipated that family-work conflict among contract workers will be worse. Upon all this, we could not find any published studies on family-work conflict and safety performance in the context of the Ghanaian mining industry. This current study will therefore seek to investigate the predictive nature of family-work conflict on safety performance among contract mineworkers and also examine the mediating role of job stress in the relationship between family-work conflict safety performance of contract mineworkers in Tarkwa-Ghana (see Figure 1).

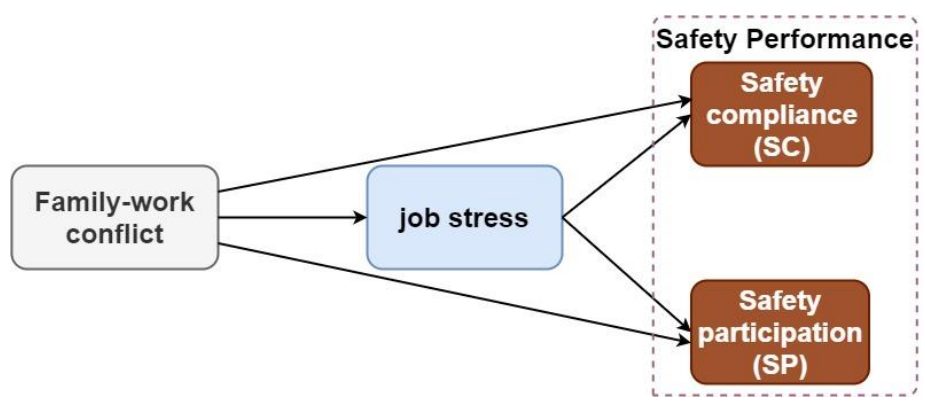

Figure 1 A conceptual framework illustrating the relationships among family-work conflict, job stress and safety performance

Family-work conflict is classified as a workplace hazard, and it has a significant impact on employee performance (Karatepe \& Sokmen, 2006; Netemeyer, Maxham, \& Pullig, 2005; Smith \& DeJoy, 2012). Also, some previous studies have suggested a negative relationship to exist between family-work conflict and safety performance (Cullen \& Hammer, 2007; Turner, Hershcovis, Reich, \& Totterdell, 2014; Wu et al., 2018). Most mineworkers work more hours in a week and often have little time to spare with family members. Unfavourable work schedules can make some family members perceive that such 
employees are shirking away from their responsibilities such as helping the kids with their homework, attending family gatherings, taking the kids out to play etc. This condition can also create inter-family conflicts and compel family members to interfere with the work of the employees (KowalsKi-traKofler et al., 2011). Anytime an imbalance occurs between one's family and his or her work, performance is it that suffers. As familywork conflict increases, so shall safety performance deteriorate due to malicious work behaviour (Johnson, Eatough, Hammer, \& Truxilllo, 2019; Smith et al., 2018). Therefore, this study hypothesises that:

H1: family-work conflict is a crucial predictor of safety performance.

H1a: Family-work conflict has a significant influence on safety compliance.

H1b: Family-work conflict has a significant influence on safety participation

For mineworkers, the time and effort they spend at work are often more than what they spend with their family (Hongxia, Yongbin, Shuicheng, Fen, \& Huan, 2014). This situation can result in insurmountable pressure for the workers and increase their stress level. Hongxia et al. (2014) also highlighted that workers whose family affairs interfere more with their work exhibited poor safety performance. As employees fail to balance their work activities with their family activities, so will their stress level continue to increase (Turner et al., 2014). In the work of Wu et al. (2018), they found a significant negative relationship to exist between family-work conflict. They concluded in their study that employees who have little ability to balance their family demands with that of their work demands performed low in the aspect of safety compliance and safety participation. From this background, this study hypothesises that:

$\mathrm{H} 2$ : Family-work conflict is significantly related to job stress.

H3: Job stress has a significant relationship with safety performance.

H3a: Job stress has a significant influence on safety compliance.

$\mathrm{H} 3 \mathrm{~b}$ : Job stress has a significant influence on safety participation.

The family-work conflict has been suggested to have a critical impact on employees' work performance, especially safety performance. However, they do so by inducing individual employees to be stressed up. Family-work conflict is a component of stressors (Cooper \& Marshall, 1978; Netemeyer, Boles, \& McMurrian, 1996; Wu et al., 2018). Job stress has been suggested to play a significant mediating role in the relationship between stressors and safety performance. Since family-work conflict is a component of stressors, and it can influence job stress, and job stress, in turn, can influence safety performance, it can be hypothesised that:

H4: Job stress will play a significant mediating role in the relationship between family-work conflict and safety performance

H4a: Job stress will play a significant mediating role in the relationship between family-work conflict and safety compliance H4b: Job stress will play a significant mediating role in the relationship between family-work conflict and safety participation

\subsection{Population and Sample}

\section{Methods}

Ghana is a country of several natural resources. Most of Ghana's natural resources are located in its Western region and Tarkwa, a famous city in Western is known for its gold reserve. Three prominent mining companies are operating in Tarkwa (thus, two gold mining companies and one manganese mining company). These well-known mining companies are often referred to as mother companies because aside from their employees, some other aspects of their operations are done by different companies. The contractors and sub-contractors are often under pressure to achieve a high target to impress the mother companies. Employees of these contractors are often expected to manage work pressure as well as family pressure and perform well at the same time. Therefore, this study was conducted for only employees of mine-contractors operating in the mines in Tarkwa. Questionnaires were distributed to 405 contract mineworkers after authorisation had been sought from employees' managers, union leaders and employees themselves. The questionnaires contained questions about demographics (e.g. gender, age, marital status, educational level and years of working experience), family-work conflict, job stress and safety performance. The respondents were given education about the essence of the study and assured that there were no wrong or right answer to any question. They were requested to provide an honest response to the questions. The respondents were also assured of full anonymity and confidentiality of their responses. The researchers personally collected 377 questionnaires from the respondents out of which 302 responses were filled and were valid.

\subsection{Survey Instruments}

\subsubsection{Family-work conflict scale}

The family-work conflict scale was developed by Netemeyer et al. (1996) through extensive literature review and collecting responses from 182 elementary and high school teachers and administrators. In this present study, the family-work conflict scale was adopted to measure the kind of stressful event employees could perceive and the extent of conflict that affected employees' safety performance in the extractive sector. The scale contained five items, and it was measured with a 5-point $(1-5)$ Likert scale ranging from $1=$ strongly disagree, $2=$ agree, $3=$ not sure, $4=$ agree to $5=$ strongly agree. Since the family-work conflict scale was being used for the first time in a study of this kind, it was essential to establish its psychometric properties before being used in the final survey. The scale was first piloted on forty-three employees, and its reliability was 0.76 . It was retested on additional 65 employees, and its Cronbach alpha was 0.86 , indicating excellent reliability. We, therefore, accepted to employ the scale for the final survey analysis. All respondents chosen for the pilot and re-pilot studies were excluded from the final survey analysis.

\subsubsection{Perceived Stress Scale (PSS)}

The 10-item perceived stress scale (PSS) developed by Cohen, Kamarck, and Mermelstein (1983). It has received a lot of recognition in areas such as education (Reis, Hino, \& RodriguezAñez, 2010), police service (Wang et al., 2011), the health sector (Mimura \& Griffiths, 2004) etc. but less recognition in the 
mining industry most especially Ghanaian mining industry. Therefore, this present study adopted the PSS to assess the level of job stress perceived by employees in the Ghanaian mining sector. Before finally accepting to use the PSS, we first performed a pilot study using forty-three employees and checked the reliability of the scale. The Cronbach alpha for the piloted scale was 0.80 . We again re-piloted the scale using different 65 employees and Cronbach alpha recorded was 0.82 indicating very good reliability. Therefore, we accepted to employ the scale for the final survey analysis. All respondents chosen for the pilot and re-pilot studies were excluded from the final survey analysis.

\subsubsection{Safety Performance}

The safety performance construct was measured with ten items from the safety performance scale developed by DeArmond, Smith, Wilson, Chen, and Cigularov (2011). Four out of the ten items measured safety compliance and the remaining six items measured safety participation behaviour of employees.

\subsubsection{Control Variables}

Five demographics were gathered and added during hypotheses testing to control for confounding effects. The controls were gender, age, marital status, educational level and working experience. These controls might influence safety performance and have been widely used safety literature (Guo, Yiu, \& Gonzalez, 2018; Ye, Ren, Li, \& Wang, 2020).

\section{Data Analysis}

This study used both SPSS version 26 and AMOS version 26 for the data analysis. The SPSS was used to perform the preliminary such as the exploratory factor analysis. Structural equation model (SEM) with AMOS 26 was used to assess the data about the effects of family-work conflict, job stress and employee-work experience on safety performance.

\subsection{Demographic characteristics \\ 4. Results}

Results from the data showed that $156(51.7 \%)$ out of the 302 responses were male respondents, and $146(48.3 \%)$ respondents were females. The ages of the respondents from $20-30$ were 28 (9.27\%), 31 - 40 were $110(36.42 \%), 41-50$ were $151(50 \%)$ and $13(4.31 \%)$ respondents were above 50 years. Regarding the marital status of the respondents, there were $156(51.7 \%)$ respondents who were married, $78(25.8 \%)$ were never married, 55 (18.2 had married before but divorced, and 13 (4.3\%) were either widows or widowers. Concerning the educational level of the participants, $131(43.4 \%)$ of them had either bachelor or higher national diploma certificate, 165 (54.6\%) had senior high school certificate, and $6(2.0 \%)$ had a junior high school certificate. Finally, the demographics are the years of working experience of the respondents. $6(2.0 \%)$ of the respondents had less than 1-year working experience, 16 (5.3\%) had working experience from 1 to 5 years, $62(20.5 \%)$ had from 6 to 10 years working experience, and $218(72.2 \%)$ had more than ten years working experience.

\subsection{Reliability, validity and inter-factor correlation analysis}

Table 1 shows the factors loadings of both exploratory and confirmatory factor analyses, average variance extracted, composite reliability and Cronbach alpha values. This study performed two kinds of factor analyses to check the reliability and validity of the scales chosen. They included exploratory and confirmatory factor analyses. The exploratory factor analysis revealed that all the items appropriately loaded under their predicted factors. The Kaiser-Meyer-Olkin Measure (KMO) of Sampling Adequacy for all the four scales was 0.894, and it was significant at 0.001 . The four scales had a total eigenvalue of 14.359 that accounted for $57.437 \%$ of the total variances explained. The study also performed a common bias test by setting the number of factors to be extracted to one (1) using SPSS. The outcome revealed that only $28.72 \%$ of the total variance could be explained by just one factor. Since the variance explained by one factor was less than $50 \%$, it will not be erroneous to suggest that our data did suffer from common method biases.

The study performed further analysis to establish additional support for the data. Therefore, confirmatory factor analysis was performed using AMOS version 26.0 software. Except for one item belonging to the safety compliance scale, which recorded a standardised factor loading of 0.496 and was significant, all other item had a standardised factor loading greater than 0.50. The measurement fit indices for the measurement model (see Figure 2 ) revealed a Chi-square $\left(\left(\mathrm{X}^{2}\right)=\right.$ 405.122 , degree of freedom $(\mathrm{df})=269$, normed Chi-square ratio $\left(\mathrm{X}^{2} / \mathrm{df}\right)=1.506$, standardized root mean square residual (SRMR) $=0.050$, root mean square error of approximation (RMSEA) $=0.041$, PClose $=0.969$, comparative fit index $(\mathrm{CFI})=959$, Tucker-Lewis fit index TLI $=0.954$ and they fit the data well. The Cronbach alphas and composite reliabilities for the factors were either 0.75 or more indicating good internal consistencies. Except for the average variance extracted (AVE) for the safety participation, which was 0.582 , any other factor in the study had an AVE less than the 0.50 threshold. According to Malhotra and Dash (2011), AVE is too hence establishing reliability through composite reliability alone is acceptable. The discriminant validity values from the square the root of the AVE for familywork conflict, job stress, safety compliance and safety participation were also greater than the associated latent variables correlations (see Table 2).

Table 1 Validity and reliability of the scales

\begin{tabular}{lllllll}
\hline Variable & $\begin{array}{l}\text { Item } \\
\text { code }\end{array}$ & $\begin{array}{l}\text { CFA } \\
\beta\end{array}$ & $\begin{array}{l}\text { EFA } \\
\beta\end{array}$ & AVE & CR & $\begin{array}{l}\text { Cron } \\
\text { Alph }\end{array}$ \\
\hline Family- & FWC2 & .697 & 0.757 & 0.462 & 0.811 & .811 \\
work & & & & & & \\
conflict & & & & & & \\
(FWC) & & & & & & \\
& FWC1 & 0.667 & 0.756 & & & \\
& FWC5 & .716 & 0.708 & & & \\
& FWC4 & .655 & 0.705 & & & \\
Job stress & JS10 & .661 & 0.657 & & & \\
(JS) & & & 0.758 & 0.452 & 0.891 & .890 \\
& JS3 & .728 & 0.701 & & & \\
& JS2 & .713 & 0.689 & & & \\
& JS4 & .683 & 0.687 & & & \\
& JS5 & .639 & 0.672 & & &
\end{tabular}




\begin{tabular}{lllllll} 
& JS6 & .682 & 0.655 & & & \\
& JS1 & 0.638 & 0.648 & & & \\
& JS7 & .626 & 0.625 & & & \\
& JS8 & .656 & 0.587 & & & \\
& JS9 & .672 & 0.57 & & & \\
Safety & SC3 & .764 & 0.805 & 0.458 & 0.768 & .757 \\
compliance & & & & & & \\
(SC) & & & & & & \\
& SC2 & .714 & 0.784 & & & \\
& SC1 & 0.703 & 0.756 & & & \\
Safety & SC4 & .496 & 0.617 & & & \\
participation & SaP5 & .992 & 0.861 & 0.582 & 0.89 & .877 \\
(SaP) & & & & & & \\
& & & & & & \\
& SaP4 & .824 & 0.797 & & & \\
& SaP3 & .733 & 0.763 & & & \\
& SaP1 & 0.621 & 0.742 & & & \\
& SaP2 & .694 & 0.729 & & & \\
& SaP6 & .650 & 0.672 & & & \\
& & & & & & \\
\hline
\end{tabular}

Table 2 Inter-factor correlation matrix

\begin{tabular}{lllll}
\hline Variable & 1 & 2 & 3 & 4 \\
\hline 1.Family-work conflict & $\mathbf{0 . 6 8}$ & & & \\
2. Job stress & $0.445^{* * *}$ & $\mathbf{0 . 6 7 2}$ & & \\
3. Safety compliance & $-0.337^{* * *}$ & $-0.352^{* * *}$ & $\mathbf{0 . 6 7 7}$ & \\
4. Safety participation & $0.184^{* *}$ & $-0.548^{* * *}$ & 0.013 & $\mathbf{0 . 7 6 3}$ \\
\hline
\end{tabular}

Note: $* * \mathrm{p}<0.01$, *** $\mathrm{p}<0.001$, values in bold represent discriminant validity

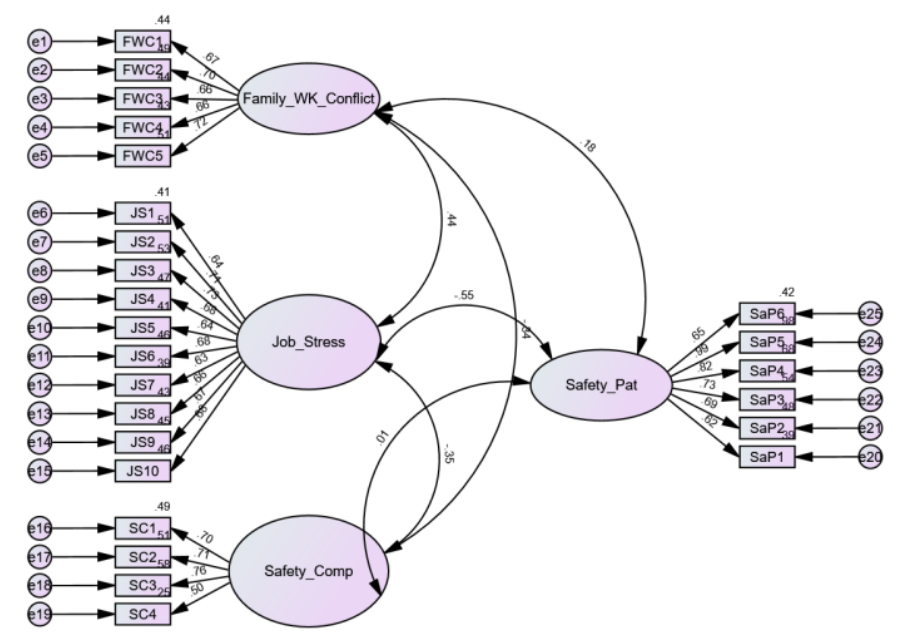

Note: Chi-square $\left(\mathrm{X}^{2}\right)=405.122, \mathrm{df}=269, \mathrm{X}^{2} / \mathrm{df}=1.506, \mathrm{SRMR}=$ 0.050, RMSEA $=0.041$, PClose $=0.969, \mathrm{CFI}=959, \mathrm{TLI}=0.954$

Figure 2. Measurement model

\subsection{Hypotheses testing}

In testing the hypotheses, the study began by assessing the effect of family-work conflict on safety performance (Hypothesis-H1). A structural model was estimated in Amos version 26 software (Figure 2). The model gave good fit with the data $\left(X^{2}=189.563\right.$, $\mathrm{df}=148, \mathrm{X}^{2} / \mathrm{df}=1.281, \mathrm{CFI}=0.98, \mathrm{SRMR}=0.042, \mathrm{TLI}=$ 0.974 , RMSEA $=0.031$ ). The standardized coefficients values from family-work conflict to safety compliance and safety participation were $-0.33(\mathrm{p}<0.001, \mathrm{t}=-4.286)$ and $0.178(\mathrm{p}<$ $0.01, \mathrm{t}=2.643$ ) respectively, providing support for $\mathrm{H} 1$ (H1a and H1b).

The study then tested the full structural mediation model (see Figure 4), where job stress was included in the main effect model (Figure 3). This method of testing the mediation is consistent with extant literature (Madrid, Diaz, Leka, Leiva, \& Barros, 2018; Ye et al., 2020).

As it has been shown in Figure 4, the structural mediation model had a good fit with the data $\left(X^{2}=518.983, \mathrm{df}=\right.$ $375, \mathrm{X}^{2} / \mathrm{df}=1.384, \mathrm{CFI}=0.959, \mathrm{TLI}=0.953, \mathrm{SRMR}=0.046$, RMSEA $=0.036)$. The standardized path coefficient from family-work conflict to job stress was 0.452 ( $\mathrm{p}<0.001 ; \mathrm{t}=$ 5.822), providing support for $\mathrm{H} 2$. Concerning the effect of job stress on safety compliance and safety participation, the standardized coefficients of the paths were $-0.218(\mathrm{p}<0.01 ; \mathrm{t}=$ $-2.84)$ and $-0.796(\mathrm{p}<0.001 ; \mathrm{t}=-7.978)$ respectively, providing support for $\mathrm{H} 3$ (H3a and $\mathrm{H} 3 \mathrm{~b}$ ).

In Table 3 are the results for the direct, indirect and total effect. The indirect effect of family-work conflict on safety compliance and safety participation through job stress recorded standardised estimates of -0.099 with $95 \%$ confidence intervals of $[-0.184,-0.025)$ and -0.36 with $95 \%$ confidence intervals of $[-0.502,-0.228]$ respectively. Thus, it provides support for $\mathrm{H} 4$ ( $\mathrm{H} 4 \mathrm{a}$ and $\mathrm{H} 4 \mathrm{~b}$ ).

Table 3. Analysis of the direct, indirect and total effect

\begin{tabular}{|l|l|l|}
\hline Predictors & Safety compliance & $\begin{array}{l}\text { Safety } \\
\text { participation }\end{array}$ \\
\hline Direct effects & $\beta$ & $\beta$ \\
\hline Family-work conflict & $-0.251^{* *}$ & $0.547 * * *$ \\
\hline Job stress & $-0.218^{* *}$ & $-0.796^{* * *}$ \\
\hline Indirect effect & $\beta(95 \% \mathrm{CI})$ & $\beta(95 \% \mathrm{CI})$ \\
\hline $\begin{array}{l}\text { FWC--->JS--->SC } \\
F W C--->J S--->S a P\end{array}$ & $-0.099 * *(-0.184,-$ & $-0.36^{* * *} \quad(-0.502$, \\
\hline $\begin{array}{l}\text { Total effects of family- } \\
\text { work conflict }\end{array}$ & $-0.349 * * *$ & $-0.1286^{* *}$ \\
\hline
\end{tabular}

Note: $* * \mathrm{p}<0.01 ; * * * \mathrm{p}<0.001,95 \% \mathrm{CI}$ based on 5,000 bootstrapping. Abbreviations: $\mathrm{FWC}=$ family-work conflict; JS = job stress; $\mathrm{SC}=$ safety compliance, $\mathrm{SaP}=$ safety participation 


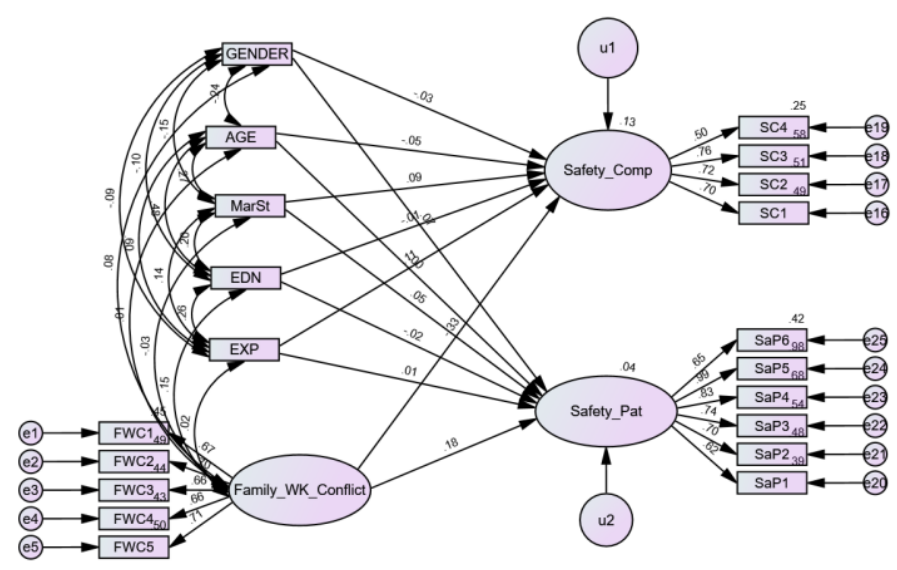

Model fit: $\mathrm{X} 2=189.563, \mathrm{df}=148, \mathrm{X} 2 / \mathrm{df}=1.281, \mathrm{CFI}=0.98, \mathrm{SRMR}=$ 0.042, RMSEA $=0.031$, PClose $=0.997$

Figure 3 Main effect model

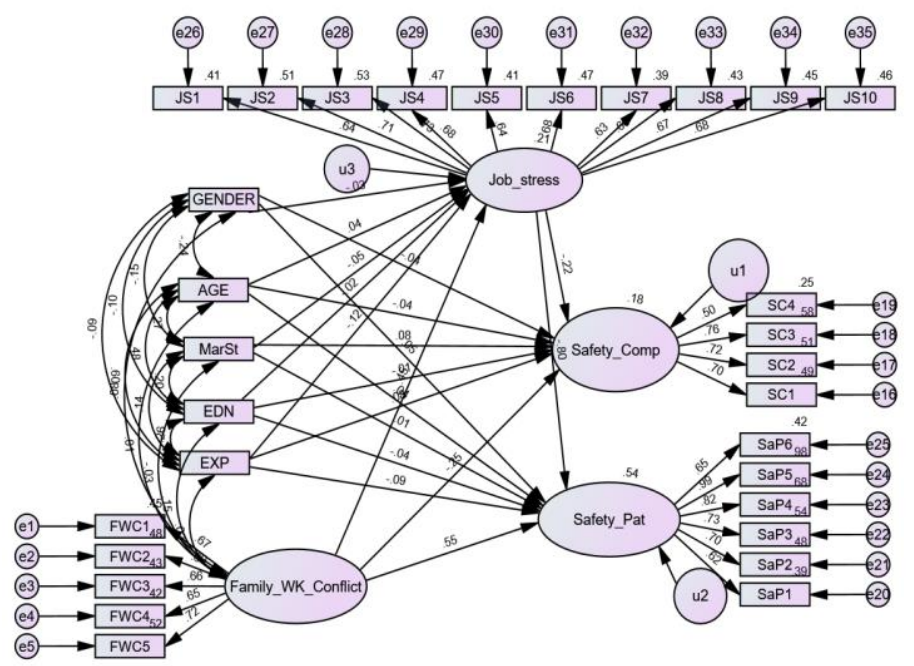

Model fit: $\left(\mathrm{X}^{2}=518.983 ; \mathrm{df}=375 ; \mathrm{X}^{2} / \mathrm{df}=1.384 ; \mathrm{CFI}=0.959 ; \mathrm{TLI}=\right.$ 0.953; $\mathrm{SRMR}=0.046 ;$ RMSEA $=0.036$ )

Abbreviations: MarSt $=$ marital status; $\mathrm{EDN}=$ educational level; $\mathrm{EXP}=$ employee-work experience; Family_WK_Conflict = family-work conflict; Safety_Comp = Safety compliance; Safety_Pat $=$ Safety participation

Figure 4 Structural mediation model

\section{Discussions}

The current study sought to validate the reliability of the familywork scale, and the perceived stress in the context of the mining industry. The reliability of the scales chosen for this particular study has been proven to have high internal consistencies. The study also sought to examine the effect of family-work conflict on safety performance through the mediating role of job stress. Findings from the study revealed that family-work conflict has a significant negative influence on safety compliance which confirms similar findings obtained by and a significant positive influence on safety participation. These findings contradict findings in the work of Eatough, Johnson, Chang, Hammer, and Truxilllo (2018) who found no significant relationship to exist between family-work conflict and safety performance. The findings of this study, however, provides support for findings in the work of Cullen and Hammer (2007). When employees often encounter demands from their families that conflict with their work, employees' behaviours are likely to be affected (Frone, Russell, \& Cooper, 1992). Employees who experience higher family-work conflict may have troubles focusing on the best safety approaches for executing roles. Such employees may decrease safety behaviours, such as safety compliance than employees who experience lesser family-work conflicts (Cullen \& Hammer, 2007). The positive significant impact family-work conflict had on safety participation could be because some employees who do not have the peace of mind at may prefer to spend more hours at the workplace. Such employees may choose to engage in several extra work activities (e.g. safety participation) that will take much of their daily 24 hours, thereby spending fewer hours with their family.

Findings from the results of the study also demonstrated that family-work conflict has a significant positive influence on job stress providing support for findings in some similar studies like Turner et al. (2014) and Hongxia et al. (2014). As family-work conflict increases so will job stress among contract workers increase.

Job stress also exhibited a significant negative influence on safety compliance and safety participation thereby confirming findings in some similar previous studies like Khuong and Yen (2016) and Mimura and Griffiths (2003) even though our study considered a more specific aspect of performance. Employees who encounter more job stress may suffer from physical stress (e.g. headache, lower backache and insomnia) of psychological stress (e.g. nervousness, anger, sadness and fear). These symptoms may cause the health of the employee to deteriorate and consequently affect their general performance including safety performance (Leung, Liang, \& Olomolaiye, 2016; Zhu, Quansah, Obeng, \& Cobbinah, 2020).

Concerning findings from results, job stress had a partial mediation effect in the relationship between family-work conflict and the factors of safety performance. This outcome is in line with similar studies (e.g. Leung, Chan, and Yu (2012), Abbe, Harvey, Ikuma, and Aghazadeh (2011), Khuong and Yen (2016) etc.) that have suggested that job stress has a mediating ability in the relationships between antecedents of stress and employee performance.

Besides the findings of this present study, both theoretical and practical contributions have also been made. Theoretically, this study has demonstrated that family-work conflict has both a direct and indirect effect on safety compliance and safety participation through the mediating role of job stress. Practically, the negative and positive impact of family-work conflict on safety compliance and safety participation respectively will have serious managerial implications. As employees continue to experience more stress, their desire, and concentration to practice safety participation diminish. Lower compliance to safety standards will result in higher injuries and even fatal accidents (Leung et al., 2016; Siu, Phillips, \& Leung, 2004; Stemn, Bofinger, Cliff, \& Hassall, 2019).

Furthermore, organisations exist to provide economic relief and other life security. Organisations do exist to dismantle or create broken homes. Organisations must have systems in place to 
quickly identify employees whose family issues due to their work and help solve them immediately.

\section{Limitations and suggestions for future studies}

Though the outcomes of the study extend and improve previous literature, it is advisable to appreciate some possible limitations. First, the study used self-response data. Using self-reporting data has a high possibility of generating common method biases. To reduce the possibility of common method biases, the researchers assured the respondents of maximum anonymity. Items such as name and worker's code were eliminated from the questionnaire. The respondents were told that there were no right or wrong answers and that they should respond to the questions with all honesty. This method reduces one's evaluation apprehension, making them less possibly to edit their answers to be more socially desirable, lenient, acquiescent and consistent with their perception about the expectations from the researcher (Podsakoff, MacKenzie, Lee, \& Podsakoff, 2003). Results of the common method bias test show that the study did not have any issues of common method biases since none of the factors could explain more than $50 \%$ of the variance. Second, the study only considered one antecedent of stress to influence safety performance. There are several other antecedents of stress this study could have included in the survey analysis. Future studies should consider more antecedents of stress such as factors intrinsic to the job aspect, organisational style and interpersonal relationships to ascertain more appropriate information on how different stressors affect different safety performance in a single model. Additionally, the study considered only contract mineworkers in Tarkwa, which makes generalising of the findings inappropriate. The researchers will consider a broader scope by including mineworkers in other parts of Ghana and workers from different fields such as construction, education, health etc.

\section{APPENDIX}

\section{Questionnaire}

\begin{tabular}{|c|c|c|}
\hline Variable & $\begin{array}{l}\text { Item } \\
\text { code }\end{array}$ & Item / question /statement \\
\hline \multirow[t]{5}{*}{$\begin{array}{l}\text { Family-work } \\
\text { conflict (FWC) }\end{array}$} & FWC1 & $\begin{array}{l}\text { The demands of my family or } \\
\text { spouse/partner interfere with } \\
\text { activities }\end{array}$ \\
\hline & FWC2 & $\begin{array}{l}\text { I have to put off doing things at work } \\
\text { because of demands on my time at home. }\end{array}$ \\
\hline & FWC3 & $\begin{array}{l}\text { Things I want to do at work don't get done } \\
\text { because of the demands of my family or } \\
\text { spouse/partner. }\end{array}$ \\
\hline & FWC4 & $\begin{array}{l}\text { My home life interferes with my } \\
\text { responsibilities at work, such as getting to } \\
\text { work on time, accomplishing daily tasks, and } \\
\text { working overtime. }\end{array}$ \\
\hline & FWC5 & $\begin{array}{l}\text { Family-related strain interferes with my } \\
\text { ability to perform job-related duties. }\end{array}$ \\
\hline \multirow[t]{4}{*}{ Job stress (JS) } & JS1 & $\begin{array}{l}\text { In the last month, how often have you } \\
\text { been upset because of something that } \\
\text { happened unexpectedly? }\end{array}$ \\
\hline & JS2 & $\begin{array}{l}\text { In the last month, how often have you } \\
\text { unable to control the important things in your } \\
\text { life }\end{array}$ \\
\hline & JS3 & $\begin{array}{l}\text { In the last month, how often have you felt } \\
\text { nervous and 'stressed'? }\end{array}$ \\
\hline & JS4 & In the last month, how often have you \\
\hline
\end{tabular}

\begin{tabular}{|c|c|c|}
\hline & & $\begin{array}{l}\text { confident about your ability to handle your } \\
\text { personal problems? }\end{array}$ \\
\hline & JS5 & $\begin{array}{l}\text { In the last month, how often have you felt } \\
\text { that things were going your way? }\end{array}$ \\
\hline & JS6 & $\begin{array}{l}\text { In the last month, how often have you } \\
\text { found that you could not cope with all the } \\
\text { things that you had to do? }\end{array}$ \\
\hline & JS7 & $\begin{array}{l}\text { In the last month, how often have you } \\
\text { been able to control irritations in your life? }\end{array}$ \\
\hline & JS8 & $\begin{array}{l}\text { In the last month, how often have you felt } \\
\text { that you were on top of things? }\end{array}$ \\
\hline & JS9 & $\begin{array}{l}\text { In the last month, how often have you } \\
\text { been angered because of things that were } \\
\text { outside of your control? }\end{array}$ \\
\hline & JS10 & $\begin{array}{l}\text { In the last month, how often have you felt } \\
\text { difficulties were piling up so high that you } \\
\text { could not overcome them? }\end{array}$ \\
\hline $\begin{array}{l}\text { Safety } \\
\text { compliance (SC) }\end{array}$ & $\mathrm{SC} 1$ & $\begin{array}{l}\text { I minimise exposure to hazards by using } \\
\text { the appropriate work practices }\end{array}$ \\
\hline & $\mathrm{SC} 2$ & $\begin{array}{l}\text { I use the correct personal protective } \\
\text { equipment as indicated by the mine's health } \\
\text { and safety plan }\end{array}$ \\
\hline & SC3 & $\begin{array}{l}\text { I use the right steps if denied from or } \\
\text { penalised for exercising my rights under } \\
\text { OSHA policies and procedures }\end{array}$ \\
\hline & SC4 & $\begin{array}{l}\text { I appropriately report injuries, accidents, } \\
\text { or illnesses to my superiors }\end{array}$ \\
\hline $\begin{array}{c}\text { Safety } \\
\text { participation }(\mathrm{SaP})\end{array}$ & $\mathrm{SaP} 1$ & $\begin{array}{l}\text { I help others to ensure they do their work } \\
\text { safely }\end{array}$ \\
\hline & $\mathrm{SaP} 2$ & $\begin{array}{l}\text { I explain to others why I will report safety } \\
\text { violations }\end{array}$ \\
\hline & $\mathrm{SaP} 3$ & $\begin{array}{l}\text { I try to change the way the job is done to } \\
\text { make it safer }\end{array}$ \\
\hline & $\mathrm{SaP} 4$ & $\begin{array}{l}\text { I voice out and encourage others to get } \\
\text { involved in safety issues }\end{array}$ \\
\hline & $\mathrm{SaP5}$ & $\begin{array}{l}\text { I take actions to prevent safety violations } \\
\text { in order to protect the well-being of other } \\
\text { crew members }\end{array}$ \\
\hline & SaP6 & $\begin{array}{l}\text { I attend non-mandatory safety-oriented } \\
\text { training }\end{array}$ \\
\hline
\end{tabular}

\section{ACKNOWLEDGMENT}

Thanks to Mr Patrick Afadzie Fanyinkah of African Mining Service and Mr Collins Ewudzie Quansah of Rana Motors Ghana Limited for their support during the data collection process.

\section{REFERENCES}

Abbe, O. O., Harvey, C. M., Ikuma, L. H., \& Aghazadeh, F. (2011). Modeling the relationship between occupational stressors, psychosocial/physical symptoms and injuries in the construction industry. International Journal of Industrial Ergonomics, 41(2), 106-117.

Cohen, S., Kamarck, T., \& Mermelstein, R. (1983). A global measure of perceived stress. Journal of Health and Social Behavior, 24, 385-396.

Cooper, C. L., \& Marshall, J. (1978). Understanding executive stress: Springer.

Cullen, J. C., \& Hammer, L. B. (2007). Developing and testing a theoretical model linking work-family conflict to employee safety. Journal of occupational health psychology, 12(3), 266.

DeArmond, S., Smith, A. E., Wilson, C. L., Chen, P. Y., \& Cigularov, K. P. (2011). Individual safety performance in the construction industry: Development and validation of two short scales. Accident Analysis \& Prevention, 43(3), 948-954.

Eatough, E. M., Johnson, R. C., Chang, C.-H. D., Hammer, L. B., \& Truxilllo, D. (2018). Home is where the mind is: Family interference with work and safety performance in two high risk industries Journal of vocational behavior, 18. doi:10.1016/j.jvb.2018.10.012 
Frone, M. R., Russell, M., \& Cooper, M. L. (1992). Antecedents and outcomes of work-family conflict: Testing a model of the work-family interface. Journal of applied psychology, 77, 65-78.

Greenhaus, J. H., \& Beutell, N. J. (1985). Sources and conflict between work and family roles. Academy of Management review, 10(1), 76-88.

Guo, B. H., Yiu, T. W., \& Gonzalez, V. A. (2018). Does company size matter? Validation of an integrative model of safety behaviours across small and large construction companies. Journal of safety research, 50(4), 309-275.

Hongxia, L., Yongbin, F., Shuicheng, T., Fen, L., \& Huan, L. (2014). Study on the job stress of miners. Procedia engineering, 84, 239-246.

Johnson, R. C., Eatough, E. M., Hammer, L. B., \& Truxilllo, D. (2019). Home is where the mind is: Family interference with work and safety performance in two high risk industries. Journal of vocational behavior, 110, 117-130.

Karatepe, O. M., \& Sokmen, A. (2006). The effects of work role and family role variables on psychological and behavioral outcomes of frontline employees. Tour. Manag, 27, 255-268.

Khuong, M. N., \& Yen, V. H. (2016). Investigate the Effects of Job Stress on Employee Job Performance--A Case Study at Dong Xuyen Industrial Zone, Vietnam. International Journal of Trade, Economics and Finance, 7(2), 31 .

KowalsKi-traKofler, K. M., Vaught, C., McWilliams, L. J., \& Reisman, D. (2011). Psychological and behavioral aspects of occupational safety and health in the US coal mining industry'. Occupational health and safety, 197-214.

Leung, M.-y., Chan, I. Y. S., \& Yu, J. (2012). Preventing construction worker injury incidents through the management of personal stress and organisational stressors. Accident Analysis \& Prevention, 48, 156-166.

Leung, M.-y., Liang, Q., \& Olomolaiye, P. (2016). Impact of job stressors and stress on the safety behavior and accidents of construction workers. Journal of Management in Engineering, 32(1), 04015019.

Madrid, H. P., Diaz, M. T., Leka, S., Leiva, P. I., \& Barros, E. (2018). A finer grained approach to psychological capital and work performance. Journal of Business \& Psychology, 33, 461-477.

Malhotra, N., \& Dash, S. (2011). Marketing Research: An Applied Orientation (pp. 552-582): Prentice Hall.

Mimura, C., \& Griffiths, P. (2003). The effectiveness of current approaches to workplace stress management in the nursing profession: an evidence based literature review. Occupational and environmental medicine, $60(1), 10-15$

Mimura, C., \& Griffiths, P. (2004). A Japanese version of the perceived stress scale: translation and preliminary test. International journal of nursing studies, 41, 379-385.

Netemeyer, R. G., Boles, J. S., \& McMurrian, R. (1996). Development and validation of work-family conflict and family-work conflict scales. Journal of applied psychology, 81(4), 400.

Netemeyer, R. G., Maxham, J. G., \& Pullig, C. (2005). Conflicts in the WorkFamily Interface: Links to Job Stress, Customer Service Employee Performance, and Customer Purchase Intent. J. Mark, 3, 176-180.

Podsakoff, P. M., MacKenzie, S. B., Lee, J.-Y., \& Podsakoff, N. P. (2003). Common method biases in behavioral research: A critical review of the literature and recommended remedies. Journal of applied psychology, 88(5), 879.

Reis, R. S., Hino, A. A. F., \& Rodriguez-Añez, C. (2010). Perceived Stress Scale: Reliability and Validity Study in Brazil. Journal of Health Psychology, 15(1), 107-114. doi:10.1177/1359105309346343
Siu, O.-L., Phillips, D. R., \& Leung, T.-w. (2004). Safety climate and safety performance among construction workers in Hong Kong: The role of psychological strains as mediators. Accident Analysis \& Prevention, 36(3), 359-366

Smith, T. D., \& DeJoy, D. M. (2012). Occupational injury in America: An analysis of risk factors using data from the General Social Survey (GSS). Journal of safety research, 43(1), 67-74.

Smith, T. D., Hughes, K., DeJoy, D. M., \& Dyal, M.-A. (2018). Assessment of relationships between work stress, work-family conflict, burnout and firefighter safety behavior outcomes. Safety science, 103, 287-292.

Stemn, E., Bofinger, C., Cliff, D., \& Hassall, M. E. (2019). Examining the relationship between safety culture maturity and safety performance of the mining industry. Safety science, 113, 345-355.

Turner, N., Hershcovis, M. S., Reich, T. C., \& Totterdell, P. (2014). Work-family interference, psychological distress, and workplace injuries. Journal of Occupational and Organisational psychology, 87(4), 715-732.

Wang, Z., Chen, J., Boyd, J. E., Zhang, H., Jia, X., Qiu, J., \& Xiao, Z. (2011). Psychometric properties of the Chinese version of the Perceived Stress Scale in policewomen. PloS one, 6(12), e28610.

Weer, C., \& Greenhaus, J. H. (2014). Family-to-Work Conflict. In A. C. Michalos (Ed.), Encyclopedia of Quality of Life and Well-Being Research (pp. 2210-2211). Dordrecht: Springer Netherlands.

Wu, X., Li, Y., Yao, Y., Luo, X., He, X., \& Yin, W. (2018). Development of construction workers job stress scale to study and the relationship between job stress and safety behavior: An empirical study in Beijing. International journal of environmental research and public health, 15(11), 2409 - 2420

Ye, X., Ren, S., Li, X., \& Wang, Z. (2020). The mediating role of psychological capital between pperceived management commitmentand safety behaviour. Journal of safety research, 72, 29-40.

Zhu, Y., Quansah, P. E., Obeng, A. F., \& Cobbinah, E. (2020). Investigating the Effects of Role Demands, Psychosocial Stress Symptoms and Safety Leadership on Mineworkers' Safety Performance. Psychology Research and Behavior Management, 13, 419-436.

\section{AUTHORS}

First Author - Prince Ewudzie Quansah, Ph.D Candidate, Jiangsu University,dr.peq1986@yahoo.com.

Second Author - Veronica Essinam Eggley, Mphil, University of Education, Winneba, Ghana, veeggley@uew.edu.gh.

Third Author - Kobina Danful Fanyinkah, University of Ghana, Legon, kdfanyinka@ug.edu.gh

Correspondence Author - Prince Ewudzie Quansah

School of Management, Jiangsu University,

301 Xuefu Road, Jingkou, Zhenjiang, Jiangsu

212013, People's Republic of China

email: dr.peq1986@yahoo.com. 